\title{
Qur'anic Manifestation of the Story of Maryam (PBUH): Unearthing Its Parallelistic Connection to Islamic Womanhood
}

\author{
Ibtesam AbdulAziz Bajri \\ Department of English Language, Faculty of Languages and Translation, University of Jeddah, Jeddah, Saudi Arabia \\ Email: iabajri@uj.edu.sa
}

How to cite this paper: Bajri, I. A. (2021). Qur'anic Manifestation of the Story of Maryam (PBUH): Unearthing Its Parallelistic Connection to Islamic Womanhood. Open Journal of Social Sciences, 9, 403-415. https://doi.org/10.4236/jss.2021.98028

Received: July 27, 2021

Accepted: August 24, 2021

Published: August 27, 2021

Copyright $\odot 2021$ by author(s) and Scientific Research Publishing Inc. This work is licensed under the Creative Commons Attribution International License (CC BY 4.0).

http://creativecommons.org/licenses/by/4.0/ (c) (i) Open Access

\begin{abstract}
A woman, to many, is God's most complete creation. She symbolizes independence, love, caring, gentleness and intensity in all cases. This study is a descriptive qualitative study anchored by a feminist approach and textual analysis. The researcher explores and analyzes special features of the feminism approach which appear in the story of Maryam (PBUH) in the Holy Qur'an. The events of the story are expressed in deeper thoughts and understanding to ultimately achieve relevance to Islamic womanhood. It is found out that the story of Maryam (PBUH) shows that Muslim women have a great role in spreading the message of Islam. They value the importance of energizing the Arab tradition and leadership among Arab women as viewed today. The story of Maryam (PBUH) is a model of motherhood and purity. She also stands as the personification of a dedicated teacher and a woman of wisdom.
\end{abstract}

\section{Keywords}

Islamic Womanhood, Feminist, Qur'an, Maryam (PBUH)

\section{Introduction}

In this complex world where everyone is subjected to accepting its uncertainties, literature can be considered as an avenue through which people can vent their concealed thoughts and feelings. It is an outlet for repressed ideas and emotions. In such a way, certain individuals opt to express themselves in writing, which in effect makes them understand themselves and the world better. Hence, those ideas in their work reflect society.

Literature encompasses short stories, essays, novels, and poetry. Among the 
genres of literature, poetry is the most convoluted in form and structure. Poetry is the manifestation of the writer's intricacies and discretion in putting feelings and thoughts into words.

Throughout the course of time, men and women have been compared and contrasted. History stories have been told and retold through generations of oral and visual customs. This keeps up this very ancient tradition in a very modern way. Television, motion pictures, and the internet are the new vehicles for expressing these classic tales. The value of ancient stories is still apparent in society despite the very radical changes in the way they are expressed.

Woman; to many, she is Allah's most complete creation. She signifies independence, love, considerate, gentleness, and passion, both in love and in hate. A woman is entitled to live in dignity and in freedom from want and from fear. It is a crucial means of empowering women to progress in development and reducing deficiency. It is also a fact that empowering women reflects on the health sector, families' productivity in the whole community, and value-added visions for the next generation (Gender Equality, 2021). In Islam, the position of women is very important. It will remain an issue that is relevant for negotiation in present times, both due to the difference in cultural practices in the Muslim world from the Islamic perspective and the erroneous perception in the West that Islam subjugates women (Status of Women in Islam, 2021).

The Qur'an is a book of wisdom and the word of Allah. It teaches mankind the purpose and duties of all beings; it is a divine book of shari'ah (law) because it informs man of the commands and prohibitions regarding both individual and social life. Zarabozo (1999) says that Allah describes this book as "guidance" (10). He adds what Al-Saadi (1996: 23) has noted:

It is guidance for all of the needs and benefits of the life in this world and that of the Hereafter. It is a guide for humans concerning fundamental and secondary aspects. It distinguishes truth from falsehood and what is sound from what is weak. And it makes clear to them how to follow the path that is beneficial for them in both their worldly affairs and their other worldly matters (Cited in Zarabozo, 1999: 10).

Therefore, it is mandatory for all Muslims to learn and acquire the meaning that the Holy Qur'an carries. Islam emphasizes the great importance of knowledge, learning and education.

Prophet Muhammad (PBUH) says: "Seeking knowledge is a duty incumbent on every Muslim (man or woman)". Al Khayat (2003) indicates that this saying of the Prophet "constitutes a practical Islamic requirement that illiteracy must be erased completely for both sexes" (10).

Hence, the meaning of "al-Qur'an" is "the reading" and the word "Iqra", the first word revealed, means "read" or "recite". The Holy Prophet (PBUH) says:

"O mankind! I have left behind over you that which if you hold fast to it, you will never go astray: the book of Allah and the Sunnah of His prophet." (Al Bayhaqi) (Importance of Learning the Holy Qur'an, 2021). 
Islam wants women and men to live according to it. An Islamic woman is the role model for all other non-Islamic women. She does not only accept Islam, but also practices all its teachings. She fulfills all her obligations. She is modest and respectful. She talks in a low voice and chooses her words beautifully.

Feminism has played a great role in the everyday lives of women in society. It is a philosophy that claims that men and women must have equal rights in all fields of life. The goals of feminism are similar to women's rights. It is a set of beliefs about social, political, psychological, and economic equality for both genders. It does not merely mean women's rights; rather, it means that men and women both deserve to be treated equally. Though the philosophy underlying feminism was present long ago, it took the form of a proper movement in the 1960s. This was the period when laws began to change regarding women's rights and women were thought to be equal to men rather than inferior to men.

In some Muslim spheres, the word feminism not only raises eyebrows, but also increases rigidities as women in Islam are stereotyped as being subjected to oppression, hate and inequality compared to men in Islam. Fadlallah (2009), says "[f]eminism is not an immutable and easily-defined concept; it is conditioned by history, culture, religion, and other social factors" (246). He adds, "Many women in the Islamic world define their lives within the context of Islam, and see their rights as intricately linked to it; these women define gender equality and they desire to achieve it within the context of Islam" (246). Because the Holy Qur'an is a divine, immutable Holy text held in reverence by Muslims, there is certainly not an easy path for feminists in their struggle to bring in modern feminist concepts within the faith of Islam.

In this study, the researcher gives weight to the role of women as viewed in society when it comes to sex, practice, the nature of gender inequalities, experiences, interests, and social roles based on the selected short stories along with the symbolism and imagery found in Holy Qur'an as reflected in their tradition and beliefs.

This research focuses on the story of Mariam Peace and Blessings of Allah be upon her as it has been narrated in the Holy Qur'an. The research explores the different stages of her life with some focus on her miraculous birth of her son Jesus Peace be upon him and her unique personality.

\subsection{Definition of Feminism}

Feminism is a movement that has affected the roots of most societies all over the world. Nawab (1987) defines it as "a belief that women should have economic, political, and social equality with men" (4). Hook (2000) also gives a simple definition of feminism as "a mass movement to end sexism and sexist exploitation and oppression" (11). It is a complex notion that has vast differences in meaning and connotation for people spanning generations, ethnic identities, sexual orientations, social classes, nationality, and myriad identities. Scholars like Ratna (2005) states that "[f]eminism is the concept generalization of women. A critical 
social theory which [has] the purpose ... to obtain women's right" (588), while Ritzer (2003) says that it "is a kind of critical social theory which includes social context, political, economic, and history that is facing injustice people" (448) (Cited in Suaidi \& Rusfandi, 2016: 56).

According to Humm (1990) in The Dictionary of Feminist Theory, feminism incorporates the equal rights of women and an ideology of social transformation which aims to create a world for women in social equality. She also states that "certain terms in contemporary theory, such as work, family, patriarchy, and sexuality, are used to sum up the basic experiences of women" (74). Davies (1996) in Gender Theories in Education indicates that "feminism is women's assertion of their equality with men and their demand for access to those roles and positions in public life traditionally regarded as the province of men" (62). In this study, the writer presents feminism as a way to obtain equal rights as a woman.

\subsection{Research Objectives}

This study has specific objectives to:

1) Identify the story of Maryam found in the Holy Qur'an.

2) Determine the lines/symbolism/imagery in the story.

3) Detect the textual references found in the story.

4) Recognize the role of the story in terms of women's literary history and literary tradition.

\subsection{Research Questions}

1) What are the main events in the story of Maryam (PBUH) as related in the Holy Qur'an?

2) Identify the main lines of symbolism, imagery and other metaphoric uses that appear in the story?

3) Specify the major textual references found in the story?

4) How does the story manage to reflect women's literary history and literary tradition?

5) How does the story manage to reveal the different operations (economically, politically, socially, or psychologically) of patriarchy?

\section{Review of Related Literature}

In the study of Muttaqin (2015), he analyzes the text and how the method of contextual interpretation reflects the ideological perspective of feminism as a counter-patriarchal culture. This indicates that the study is not academically convincing and the approach needs text to develop Islamic ideas. Moreover, Muttaqin agrees with Muhammad (2001), who stated that "texts do not create understanding and knowledge by themselves; it is the psychological aspect and knowledge of their readers that creates understanding" (Cited in Muttaqin, 2015: 31). This implies that the texts are understood as dependent "entity" that require others to create their meanings. This further justifies that the reader plays an 
imperative role in creating a meaningful unit of words. Thus, readers need to use their knowledge to produce a meaningful meaning. This study talks about the method of contextual interpretation, while the present study focuses on the interpretation of selected stories of the Holy Qur'an.

The undertakings of Haneef et al. (2018) focus on the issue-based analysis of Amina Wadud's (1999) reading of the pertinent Qur'anic passages on family law matters, and its main idea focuses on its methodological defects, both in terms of legal approach and outcome. It is found out that when addressing women's issues in the family, there is a need for women's groups to appreciate the rationale of the law. This study focuses on a mediated universal approach in relations between men and women in the family, while the present study is on the perspective of womanhood and the role of short stories in terms of women's literacy history and literary tradition.

Kadivar (2013) defines women's rights in the light of traditional Islamic thought, which is based on a "deserts-based" notion of justice (al-'adāla al-istiḥqāqiyya). In this chapter, he recognizes the notion of justice for individuals in proportion to their "deserts", which leads to proportional equality. He describes "egalitarian justice" and "fundamental equality" in the light of Qur'anic reading, and explores how they are more in line with the spirit of the Qur'an and Islamic standards. Finally, he takes the Qur'anic verses and hadiths appealed to justify legitimate differences between men and women in the foundations of Islamic law.

In the study of Permatasari (2016), she emphasizes the unequal treatment of black women that appears in Maya Angelou's poems. By the use of feminist theory and historical and biographical approaches, she tries to understand the underlying meaning of words, lines, and stanzas of the poems "Still I Rise", "Phenomenal Woman", and "Caged Bird". The research found out that there are three types of feminism that appear in the poem: Liberal Feminism, Marxist and Socialist Feminism, and Radical Feminism. After a thorough understanding of Maya Angelou's autobiography, the researcher identifies that the poems are influenced by the life of Maya, being a black woman, being divorced, and sexually abused. The last finding states the image of black women in the three poems: a woman who leads the movement and confronts oppression, a woman who is a good person and proud of herself, and a woman who shows her voice that black people will be free. The study focuses on the underlying meaning of words, lines, and stanzas of poems, while the present study focuses on the lines, symbolism, and imagery of short stories.

The study by McDougall (2012) further explores how women with more life experience define their feminist identities. The study reveals that women's unique experiences influence the lives of other women and also the feminist identity movement towards awareness of equality. She emphasizes that "feminist identity development can be conceptualized as the ways in which women embrace and live out feminist values in their lives" (1). This study captures the feminist identity and attitude, while the present study focuses on short stories in the Holy Qur'an and their role in terms of women's literacy history and literary tradition. 
Kostic (2006) paves the way for the understanding of Adrienne Rich's poetry in feminist literary criticism. This further view on the proliferation of writing by and about women has had a decisive effect on teaching and literary criticism. This study recognizes some controversies in feminist literary criticism, while the present study focuses on short stories in the Holy Qur'an and their role in terms of women's literacy history and literary tradition.

\section{Methodology}

In the following sections, the research rationale, framework analysis, the data, and the data gathering process are presented.

\subsection{The Rationale for Endorsing This Research Method}

This study adopts the descriptive qualitative approach anchored by feminist information. The researcher finds this approach appropriate because it makes use of the processes of gathering, analyzing, and classifying data about prevailing conditions, practices, beliefs, processes, trends, and cause and effect relationships (Calderon \& Gonzales, 2018). In this research, the researcher describes and analyzes short stories through the feminist approach which appears in the selected short stories of the Holy Qur'an.

Meanwhile, the essence of feminist theory is the idea that women have been systematically oppressed and men have been historically dominant. Using this theory, the researcher explores and studies the role of woman in the selected story in the Holy Qur'an when it comes to sex, practice, the nature of gender inequalities, experience, interests, and social roles.

In addition to this, textual analysis is adopted in the study. It is the method that is widely endorsed by modern researchers to describe and interpret the characteristics of a recorded or visual message. The objective of using textual analysis is to describe the content, structure, and to identify the functions of the messages contained in texts. It goes without saying that textual analysis covers selecting the types of texts to be studied, finding out and specifying appropriate texts, and deciding which particular approach to employ in analyzing them.

\subsection{Framework Analysis}

A feminist approach is used in understanding the background and writing style and the message it conveys in terms of womanhood. This is best exemplified by employing feminist approaches, textual, life history, and oral history approaches which are incorporated into literary works. In addition, the feminist perspective focuses on diversity and liberation. How women are being viewed in society. By using these approaches, the researcher discovers the idea behind the story that is analyzed with regards to the feminist aspect of literary work.

\subsection{The Data}

This study makes use of the selected story mentioned in the Holy Qur'an. This 
story is carefully examined and analyzed regardless of genre. It is expected to unfold the life and role of women in Islam through examining the literary lines in the process.

\subsection{Data Gathering Procedure}

In collecting the data, the researcher takes the following steps:

1) Reading and understanding the selected story taken from the Holy Qur'an.

2) Giving marks in every part of the story which is related to the objectives of the study.

3) Determining the rhetorical devices, symbolism, and imagery found in the story.

4) Identifying the role of woman in the story in terms of literary tradition and history.

5) Establishing the connection between the two inputs-the story and the life of a woman.

6) Using the splendid online rendition of the world's most popular Abdullah Yusuf Ali (1937) Quran Translation in English, published alongside the original Arabic text, completed in Lahore on the fourth of April 1937.

\section{Results and Discussion}

To illustrate the way in which women have availed themselves of the opportunities granted to them by the Qur'an, the story of Maryam (PBUH) has been selected to represent the contribution of women to the development of Islam. In order to facilitate this discussion, the following aspects will be addressed:

\section{Maryam (PBUH), the Miraculous Upbringing}

Maryam's childhood was not an ordinary one. She has displayed a significant sense of faithfulness and humility ever since her birth. Both her parents knew that Allah had chosen her for a special purpose. Her mother, therefore, has devoted herself to the service of Allah since her birth. In this way, she has been pleased to seek Allah's special protection for her daughter against all evil (Nawab, 1987: 66).

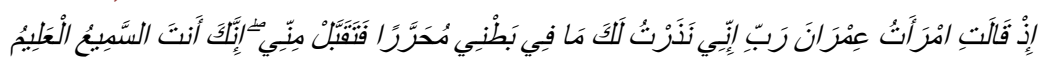

Behold! A woman of Imran said: "O my Lord! I do dedicate unto Thee what is in my womb for Thy special service, so accept this of me for Thou hearest and knowest all things." (Surat Al-Imran, 3: 35).

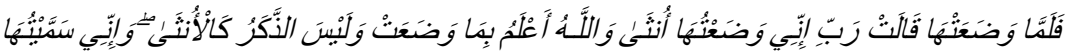

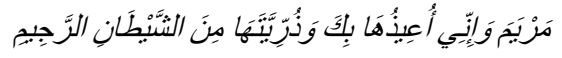

When she was delivered, she said: "O my Lord! Behold! I am delivered of a female child!" And God knew best what she brought forth "and no wise is the male like the female. I have named her Mary and I commend her and her offspring to Thy protection from the Evil One the Rejected." (Surat Al-Imran, 3: 36).

Yusuf Ali (1983) mentions: “Mary grew under God's special protection. Her 
sustenance, both physical and spiritual, came from God and her growth was strong and healthy. It was indeed a growth of purity and beauty" (137). After the death of her father, Maryam (PBUH) has been placed in the care of her maternal uncle, Zakariya. She has enjoyed a lavishness of goodness which seems to be miraculous. Zakariya has been speechless by the miraculous nurture and upbringing of Maryam (PBUH).

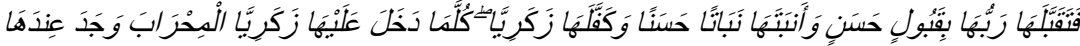

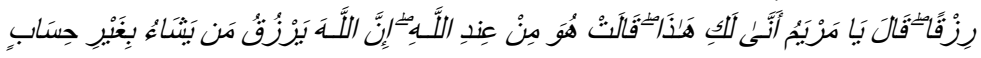

Right graciously did her Lord accept her. He made her grow in purity and beauty, to the care of Zakariya was she assigned. Every time that he entered (her) chamber to see her, he found her supplied with sustenance. He said: "O Mary! whence (comes) this to you?" She said: "From God: for God provides sustenance to whom He pleases without measure." (Surat Al-Imran, 3: 37).

\section{Maryam (PBUH), the Virgin Mother of 'Isa (Jesus) and Spirituality}

Every individual woman is created a virgin and has the same right to protect herself. This important feminine concept is reflected in the narrative content of Surat Maryam and in her characterization. The Muslim believers assign the Virgin Lady as a sign of respect and veneration. The Qur'an honors Maryam by naming an entire Surah after her. This reference to 'Isa and Maryam is used sixteen times in the Holy Qur'an, while the name of the prophet 'Isa appears on its own nine times (Nawab, 1987: 63).

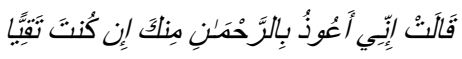

She said: "I seek refuge From thee, (God) Most Gracious. (come not near) If thou dost fear God." (Surat Maryam, 19: 18).

Allah concentrates on Maryam's purity, innocence, and motherhood message and routine life.

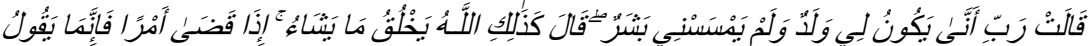

$$
\begin{aligned}
& \text { لَلَهُ كُنَ فَتَكُكُنُ }
\end{aligned}
$$

She said: "O my Lord! how shall I have a son when no man hath touched me?" He said: "Even so: God createth what He willeth; when He hath decreed a plan He but saith to it 'Be' and it is!' (Surat Al-Imran, 3: 47).

In characterization, Allah makes the female figure the main character in this Surah. HE describes women as what they really are, as the personification of Maryam (PBUH). Therefore, revelations about Muslim womanhood are emphasized. Every woman has the same opportunity to develop her future, and this liberal feminist idea is supported by the line:

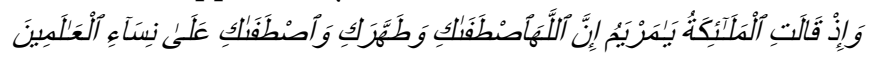

Behold! The Angels said: "O Mary! God hath chosen thee and purified thee, chosen thee above the women of all nations." (Surat Al-Imran, 3: 42).

The word "Angels" is used as a symbol in the line to signify the innocence and purity of Maryam (PBUH). She is an honored woman figure in Muslim history. Muslims view her as one of the most righteous women to have lived, and a minority views her as an actual female farsighted person. Muslim women look 
upon her as an example of spiritual figure who has created an impact on the way of living. Moreover, the spirit of humility is emphasized in the line:

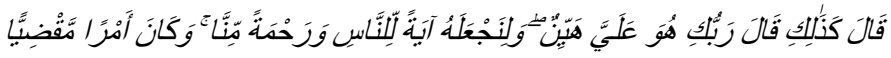

He said: "So (it will be): Thy Lord saith, 'That is Easy for Me: and(We Wish) to appoint him As a Sign unto men And a Mercy from Us: It is a matter (So) decreed" (Surat Maryam, 19: 21).

Despite being granted a spiritual position by Allah, Maryam has endured as a modest divine person. This is what is depicted in the values and approaches of Muslim women as viewed today. Her faith in Allah and her belief in the message of His apostle make her a woman of truthfulness and dedication. In this way, she has contributed to establishing spiritual Muslim women in society. Her miraculous experiences are praiseworthy examples for all women in the world.

\section{Maryam (PBUH), the Mother of a Miracle Son}

Maryam (PBUH) is unique in that she has been chosen to give birth to a son by a special miracle; "whose blessed womb bore Jesus amid social scorn" (Seedat, 16). She "has a place and a privileged role in the hierarchy of beings of this world, belonging to humanity due to the human nature she possessed, but being honoured, more than angels, due to her gift, that of giving birth [of 'Isa] in this world" (Cuțaru, 2016: 64). She stands up for her dignity and Allah consoles her with the following words:

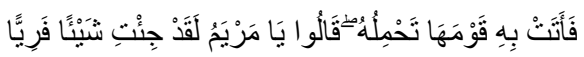

At length she brought the (babe) to her people, carrying him (in her arms). They said: "O Mary! Truly an amazing thing Hast thou brought!" (Surat Maryam, 19: 27).

People have questioned Maryam (PBUH) when she has returned with a baby in her arms. However special she may have been, they accuse and blame Maryam of betraying and disgracing her family's name. The people remind her of her esteemed ancestry, 'Imran her father, Hanna her mother, Harun her uncle.

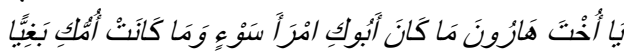

“ $O$ sister of Aaron! Thy father was not A man of evil, nor thy Mother a woman unchaste!" (Surat Maryam, 19: 28).

Her reply is to bravely point to her son:

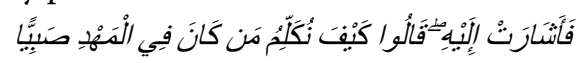

But she pointed to the babe. They said: "How can we Talk to one who is a child in the cradle?" (Surat Maryam, 19: 29).

Miraculously, the baby begins to speak from his cradle:

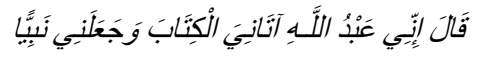

He said: "I am indeed A servant of God: He hath given me Revelation and made me a prophet," (Surat Maryam, 19: 30).

Maryam has unwavering confidence in her son, the Prophet 'Isa. He confirms, through the words of Allah:

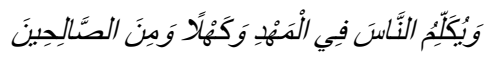

"He shall speak to the people in childhood and in maturity and he shall be (of 
the company) of the righteous." (Surat Al-Imran, 3: 4)

Despite the darkest valleys, a critical moment in Maryam's life, she still remains steadfast and very strong in her downfall and disgrace that she represents many others in this predicament. Astoundingly, the baby has become the frontrunner to show the innocence of his mother. He convinces an unbelieving audience that his mother is pure. They believed then that she was on a divine mission from Allah and that her son 'Isa is the Prophet of Allah (Yusuf Ali, 1983: 773).

These words are proof of Maryam's as an epitome of a brave, exemplary character. She has honored her chastity and purity as every woman should. She remains faithful and obedient in the face of adversity. She remains a woman of immense dignity and honor, and in these characteristics is her contribution as a Muslim woman to society at large. A Muslim woman possesses an extraordinary quality as a woman. Because of their devotion to Muslim words, their intellectual prowess to Islamic words makes them a model and inspiration. They teach everyone morals with their strength of character and dedication to Islamic knowledge, which makes them a model of inspiration not only for women, but for all Muslims, males or females. She is the epitome of a brave woman and a teacher.

\section{Conclusion}

This study aims at investigating the narrative techniques of the story of Maryam (PBUH) in the Holy Qur'an. In order to show the different narrative techniques used to establish a feminist's extraordinary and spiritual position, Allah narrates the story of Maryam (PBUH) and uses her voice, too. The researcher finds out that male consciousness of the social position of Maryam (PBUH) reflects and establishes the divine role of a mother. The miracle baby's, Prophet 'Isa, (PBUH) voice in the cradle is the essence of mother's chastity. Moreover, Maryam's characteristics of immense dignity and honor as a true believer, as viewed today, are her contributions as a Muslim woman to society at large. She is a legendary woman who denotes sisterhood and motherhood. This further liberal feminist idea connotes that women are capable of receiving divine messages and learning if given opportunities. Her faith and dedication make her a woman of substance by heart and mind. The modest personality of Maryam (PBUH) is adored by Muslim women. Furthermore, the selected story reflects the idea and significant feminist, which creates the same rights and every woman must have the same opportunity to protect her face and to build healthy spiritual and social values. This analysis also looks at the personal interactions between men and women to establish ground and to pave the way to introduce gender-equity into society. The issues raised in the story include provision of equal learning opportunities and rights. The upbringing of Maryam (PBUH) by her uncle, Zakariya (PBUH), is proof of women's "identity development and their subjective well-being" (Yakushko, 2007, cited in McDougall, 2012: 11). According to Diener (2000) and Yakushko (2007), well-being and self-esteem are affected by people's "cognitive 
and affective evaluations of their lives" (Cited in McDougall, 2012: 11). In addition, Carpenter and Johnson (2001) emphasize that women's identity development and social and psychological well-being correlate with women's "connection to collective self-esteem; women who fell into the passive acceptance and lower levels of revelation stages had a lower connection to collective self-esteem; women who fit into the embeddedness-emanation, active commitment, and synthesis stages, however, had higher connections to collective self-esteem" (Cited in McDougall, 2012: 14). Finally, the story of Maryam's (PBUH) birth and how she grew up to be a sincere and religious servant of Allah helps as a strong sign that one's greatness lies in his/her devotion and sincerity, and not in their social status or gender (Roslee, 2020).

\section{Conflicts of Interest}

The author declares no conflicts of interest regarding the publication of this paper.

\section{References}

(2021, July 22). Gender Equality. https://georgia.unfpa.org/en/node/9658

(2021, July 22). Importance of Learning the Holy Qur'an. http://www.quranreading.com/blog/importance-of-learning-the-holy-quran

(2021, July 22). Status of Women in Islam. https://www.ohio.edu/orgs/muslimst/downloads/brochures/Status of Women in Isla m.pdf

Al Khayat, M. H. (2003). Woman in Islam and Her Role in Human Development. World Health Organization, Regional Office for the Eastern Mediterranean. https://applications.emro.who.int/dsaf/dsa312.pdf

Al-Saadi, A. (1996). Taiseer Al-Kareem a/-Rahmaanfl Ta/seer Kalaam Al-Mannaan. Muassasah Al-Risaalah.

https://www.islamic-invitation.com/downloads/approach-and-understand-the-quran eng.pdf

Calderon, J. F., \& Gonzales, E. C. (2018). Methods of Research and Thesis Writing. National Book Store.

Carpenter, S., \& Johnson, L. E. (2001). Women Derive Collective Self-Esteem from Their Feminist Identity. Psychology of Women Quarterly, 25, 254-257.

https://doi.org/10.1111/1471-6402.00026

Cuțaru, C. (2016). Sittinā Maryam of the Muslims: Honouring the Virgin Mary in Islam. TEO, 66, 63-76.

https://www.academia.edu/31138623/Sittin\%C4\%81 Maryam of the Muslims Hono uring the Virgin Mary in Islam?auto=download

Davies, B. (1996). Gender Theories in Education. Macmillan Co. Ltd.

Diener, E. (2000). Subjective Well-Being: The Science of Happiness and a Proposal for a National Index. American Psychologist, 55, 34-43. https://doi.org/10.1037/0003-066X.55.1.34

Fadlallah, S. M. H. (2009). Muslim Cleric and Islamic Feminist. Journal of Alternative Perspectives in the Social Sciences, 1, 246-257.

https://www.semanticscholar.org/paper/Sayyid-Muhammad-Hussein-Fadlallah\%3A-M uslim-Cleric-Chamas/943233c64eb351d9eae86b637877971e3fce5d71 
Haneef, S. S. S., Yunus, S. M., \& al-Fijawi, M. F. A. (2018). Muslim Feminists' Reading of the Qur'an: A Juristic Analysis on Family Law Issues. Mazahib, 17, 1-22. https://journal.iain-samarinda.ac.id/index.php/mazahib/article/view/1056

Hook, B. (2000). Feminism Is for Everybody: Passionate Politics. South End Press.

Humm, M. (1990). The Dictionary of Feminist Theory. Ohio State University Press.

Kadivar, M. (2013). Revisiting Women's Rights in Islam. In Z. Mir-Hossieni, K. Vogt, Larsen, and C. Moe (Eds.), Gender and Equality in Muslim Family Law: Justice and Ethics in the Islamic Legal Tradition (pp. 213-234). I. B. Tauris \& Co. Ltd. http://ndl.ethernet.edu.et/bitstream/123456789/48329/1/39.pdf

Kostic, M. (2006). Feminist Theory and Practice in the Poetry of Adrienne Rich. Linguistics and Literature, 4, 71-84. http://facta.junis.ni.ac.rs/lal/lal2006/lal2006-08.pdf

McDougall, S. D. (2012). Defining Feminism: A Phenomenological Exploration of the Meaning Women Assign to Their Feminist Identities. Master Thesis Fargo, North Dakota State University.

https://library.ndsu.edu/ir/bitstream/handle/10365/26808/Defining\%20Feminism\%20 A\%20Phenomenological\%20Exploration\%20of\%20the\%20Meaning\%20Women $\% 20 \mathrm{As}$ sign\%20to\%20their\%20Feminist\%20Identities.pdf? sequence=1\&isAllowed=y

Muhammad, H. (2001). FiqhPerempuan: RefleksiKiaiatasWacana Agama dan Gender (Islamic Jurisprudence on Women's Issues). PenerbitLKiS.

Muttaqin, F. (2015). Feminist Interpretation of the Quran as an Ideological Critique against Patriarchy (An Indonesian Context). Jurnal Masyarakat \& Budaya, 17, 29-36. https://jmb.lipi.go.id/jmb/article/view/119

Nawab, S. (1987). The Contribution of Women to Muslim Society: A Study of Selected Autobiographical and Bibliographical literature. The World Book Encyclopedia, 7, 71. https://www.google.com/search?sa=X\&rlz=1C1CHZL arSA764SA764\&source=univ\&t $\underline{\mathrm{bm}=\mathrm{isch} \& \mathrm{q}=\mathrm{Nawab},+\mathrm{S} .+(1987) .+ \text { The }+ \text { Contribution }+ \text { of }+ \text { Women }+ \text { to }+ \text { Muslim }+ \text { Society }}$ $:+$ A+Study+of+Selected+Autobiographical+and+Bibliographic+literature.+The+Worl $\underline{\mathrm{d}+\text { Book+Encyclopedia },+ \text { Vol.+7:71.\&ved }=2 \text { ahUKEwjXuKHegubxAhXzmFwKHT5TDX }}$ UQjJkEegQIGxAC\&biw=1920\&bih=1013\#imgrc=FUYCIBlPWixVBM

Permatasari, I. E. (2016). An Analysis of Feminism in Maya Angelou's Poems by Using Historical and Biographical Approaches. JurnalIlmiah Bahasa dan Sastra, 3, 152-572. https://ejournal.unikama.ac.id/index.php/JIBS/article/view/1467/1270

Ratna, N. K. (2005). Sastra dan Cultural Studies: Representasi Fiksidan Fakta. Pustaka Pelajar.

Ritzer, G. (2003). Teori Sosial Postmodern. Kreasi Wacana. Seedat, F. Islam.

Roslee, N. H. (2020). 3 Beautiful Lessons from the Story of Maryam a.s. https://www.muslim.sg/articles/3-beautiful-lessons-from-the-story-of-maryam-a-s

Suaidi, S., \& Rusfandi, R. (2016). Feminism Reflected in Pride and Prejudice Novel by Jane Austin 1813. Jurnal Ilmiah Bahasa Dan Sastra, 3, 85-99. https://ejournal.unikama.ac.id/index.php/JIBS/article/view/1157

Wadud, A. (1999). Quran and Woman: Rereading the Sacred Text from a Woman's Perspective. Oxford University Press.

Yakushko, O. (2007). Do Feminist Women Feel Better about Their Lives? Examining Patterns of Feminist Identity Development and Women's Subjective Well-Being. Sex Roles, 57, 223-234. https://doi.org/10.1007/s11199-007-9249-6

Yusuf Ali, A. (1937). The Holy Qur'an Translation. Islamic Propagation Centre International. https://quranyusufali.com/19 
Yusuf Ali, A. (1983). The Holy Quran Translation and Commentary. Islamic Book Trust.

Zarabozo, J. M. (1999). How to Approach and Understand the Quran. Al-Basheer Company and Jamaal al-Din M. Zara bozo.

https://www.islamic-invitation.com/downloads/approach-and-understand-the-quran eng.pdf 